\title{
7 Conclusion: the Shū and political argument in early China
}

\author{
Die Geschichte als reine Wissenschaft gedacht und souverän geworden, \\ wäre eine Art von Lebens-Abschluß und Abrechnung für die Menschheit. \\ Die historische Bildung ist vielmehr nur im Gefolge einer mächtigen neuen \\ Lebensströmung, \\ einer werdenden Kultur zum Beispiel, \\ etwas Heilsames und Zukunft-Verheißendes, also nur dann, \\ wenn sie von einer höheren Kraft beherrscht und geführt wird \\ und nicht selber herrscht und führt. ${ }^{1}$
}

The way Shū were being refashioned in a variety of ways and texts during the Warring States suggests that around the second half of the first millennium BC Shū had developed into a genre - a genre fit to hold argumentation. Select text clusters that would resonate with the cultural capital of the wider meaning community-a conceptual projection-were now reproduced, variously, by assorted social groupings.

This development is only natural. It is typical of a society in crisis, real or imagined, that venerated texts of the past are used for thinking in the present. Past forms of written communication are taken as a model for the present, with new texts reproducing the features of their predecessors. This may happen in manifold ways, often on a scale between claims of renaissance and continuity.

When a society engages in cultural production in the manner of revival, on the one hand, it is because they consider their immediate experience as disconnected from the olden days. Now lost, the past must be re-constituted in the present to serve as a model for the future. A claimed permanency, on the other hand, posits the longevity of the past in the present. A society may thus lay claim to tradition, even if (re-)invented, in support of their present situation. While the end result is similar, the strategies and underlying concerns differ.

Consider epigrams. They were produced during the eighth and ninth centuries $\mathrm{AD}$ in the Byzantine Empire, the Greek-speaking remnant of the Roman Empire. They claim resurgence. ${ }^{2}$ In their stylised diction and 'stitched together from

1 Nietzsche, 1: 219.

2 The practice of Atticism where later authors copy the style of Attic authors was also a governing principle for many writers during the Roman empire, especially writers of the Second Sophis-

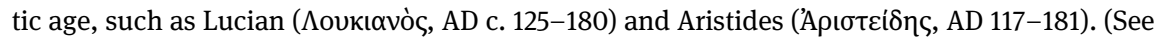

כ Open Access. @ 2021 Dirk Meyer/JAS, published by De Gruyter. (c) Er-Nc-ND This work is licensed under the Creative Commons Attribution-NonCommercial-NoDerivatives 4.0 License.

https://doi.org/10.1515/9783110708530-008 
pieces of a previous vita', ${ }^{3}$ the epigrams reconstitute the language of old to bridge the gulf between the present and the past. But while the Byzantine authors took as their basis the classical tradition, which they routinely evoke in their literary production, they also used the ancient models to bring to the fore the cultural differences between them and the ancients, thus highlighting historical change. ${ }^{4}$ Conscious of the time gap, the producers of the epigrams present themselves as both the transmitters and guardians of ancient Greek culture, but also as active transformers of that heritage. ${ }^{5}$ In their constant reproduction of texts and themes from antiquity the Byzantines draw on the familiar so as to translate their claimed heritage into cultural applications relevant for their own needs in the present, but in memory of the old. This makes these texts socio-politically and philosophically laden. By reconnecting the Byzantine Empire to past traditions and, at the same time, signalling the differences to-or developments from-the distant cultural ancestors of Byzantium, the texts stress Byzantium's special place in history. As ordained inheritors of Greek tradition, so the Byzantine self-perception, the texts hold a strong message. Not only do they claim the rightful order of Byzantine rule. Moreover they assert its necessary place in history.

Or take the literary movement associated with Hán Yù 韓愈 (768-824), the essayist and poet of the Táng 唐 Dynasty (618-907). ${ }^{6}$ Advocating a new style of writing in ancient diction, the classical movement produced by his example shares with the Byzantine epigrams claims of reconstituting the past in the present through models of resurgence. Cut off from the world of the classical period that was deemed fundamental for the present and the future, traditions had to be re-invented. One way of doing so was to produce texts that reconnect present experience with the past in the creation of something new.

Arguably, Hán Yù was formulating a philosophical claim. ${ }^{7}$ His aim was to model the self by generating the philosophical persona Mèngzǐ (aka Mencius)

Reynolds and Wilson 1991: 47). The term 'Second Sophist age' describes the literary activity of Greek writers from the second half of the first century to the first half of the third century AD.

3 Nilsson 2010: 195.

4 Nilsson 2010: 199 in reference to Green's 1982 account of Renaissance humanists' attitude to the past.

5 Nilsson 2010: 200.

6 In Western languages, there is surprising little scholarship on Hán Yù, considered by the Míng scholar Máo Kūn 茅坤 (1512-1601) as one of the 'Eight Great Masters [of Prose] of the Táng and Sòng dynasties’ (唐宋八大家). (Reference taken from de Laet 1996: 1083.) See, however, Hartman 1986; McMullen 1989 assumes a very different take on Hán Yù from Hartman.

7 As a side note, one might like to think of the eighteenth-century kăo zhèng 考證 (evidential research) movement as parallel to Hán Yù’s in spirit, yet different in method. Just like the Táng 
within oneself. This was thought best achieved by producing texts in the venerated ancient philosopher's style. ${ }^{8}$ While Hán Yù and his ideal of 'reconstituting antiquity' (fù gǔ 復古) was therefore profoundly philosophical, it also had sociopolitical implications. ${ }^{9}$ By way of producing texts in the manner of the past theso constructed-sociopolitical and philosophical order of days yore was considered to be embraced, even embodied, in the present.

The Shū texts studied in this book compare in their conclusions. That contrasting conceptual communities used (old) cultural capital in new argument space was sociopolitically and philosophically revelant. But the Warring States articulations of Shū differed in strategy. Unlike the above-cited examples, the texts of Shū genre embraced the past not as a matter of revival, but continuation. In their Gestus of self-representation, these texts do not reconnect to days yore. They act as though they were actual voices of the past, heard in the present, and relevant for the future.

\subsection{The Material Basis of Shū Genre}

Shū genre flourished in the heyday of literary manuscript cultures when during the Warring States the material availability of written sources ensured that information might flow more easily. Select text clusters of signification-clusters that were deemed to resonate with a group's cultural capital-were consequently reproduced variously and by assorted social groupings. With the increased use of such text clusters in new textual articulations, expectations rose accordingly across the different sub-groups of the wider meaning community to see them (re-)appear in certain types of sociopolitical and philosophical utterances. As the

\footnotetext{
literary movement to reinstate antiquity, scholars of the kăozhèng movement wished to restore past structures of what they perceived as true Confucian culture. To them this was best done by throwing a bridge across Neo-confucian scholarship with their Daoist and Buddhist accretions so as to resume the interrupted conversation with antiquity through the Classics, which they considered to contain 'paradigms of social order' and absolute claims to 'historical truth'. (Elman 1984: 28, also for further references.) Yet, unlike Hán Yù, their methodology to restore the past was 'philology, not philosophy'. (Elman 1984: 26-36.)

8 While Hán Yù and the movement triggered by his writings have been well described in the literature, a conceptualisation of the implicit philosophical position is yet to be written.

9 This becomes particularly obvious in the central question of imperial authority and succession, as is evident in the literary letter "Reply to Questions on Yǔ", which seems to reflect a wider debate at the time about whether the heir to the throne ought to be the son of the Emperor, or chosen on the basis of merit from outside the imperial family. See McMullen 1989: 607-608.
} 
actors in this debate are equally the recipients as well as its producers, this demand was naturally satisfied so as to ensure that these actors connect to, and remain part of, a common debate. Consciously or not, genre expectations consequently stabilised, channelling the production and reception of a particular type of texts. By assimilating modes of communication through links with previous utterances of Shū traditions, the newly produced texts-Shū-thus enabled different actors to position themselves in the debate - in and through the voice of antiquity. Intertextuality is central to this. By making use of such consolidated text clusters in the traditions of Shū, the cultural capital of the Zhōu meaning community and their various sub-groups increasingly served as a conventionalised tool for the production, reception, and circulation of discourse. With such expectations of Shū genre solidifying across the different actors of the Eastern Zhōu oecumene, the said conventions stabilised even further, governing how a stretch of discourse was organised into text. New arguments, couched in the language of days yore, were thus introduced into the debate, with deemed-legitimate precedents from high antiquity. Shū genre thus became performative in the sense that a writing-supported text performance actualised cultural knowledge for ends in the present.

The performative aspect of Shū genre thus goes beyond the oral delivery of a text to a public of whatever description. Not that this did not happen. Quite the opposite, many texts studied in this volume clearly show dramatic features that make such a text ideally suited to oral delivery. Distinct markings on the manuscripts that may well serve to signal breath groups and a change of perspectives between the personae whose voices are captured in the texts give further evidence to this. My point here is a different one. The articulation of Shū is itself a performance activity - no matter which way it was delivered. To move old cultural capital into new problem space not only enables an argument; voicing high antiquity in the present in thus prescribed form constitutes in itself the making of an argument.

During the Warring States the Shū are therefore a genre-voiced by a writingsupported text performance-which is guided by its own premises. This act of literary performance has sociopolitically and philosophically patterning ends as it enables contrasting conceptual communities to link their position to a discourse and thus take stance in a normative setting. In this way Shū genre not only governs how an argument is put. It also rules what that argument entails. 


\subsection{Evolving Shū}

Governed by its own rules of genre expectations, Shū have thus become a literary performance which textualises antiquity in a prescribed manner. Yet, the texts of Shū genre are nonetheless necessarily dynamic. They are ever-evolving products of fluctuating conceptual communities, varying with each articulation. By voicing their concerns as an expression of Shū, ever more periphal groups (or shall we say especially more periphal groups) found a way to claim unbroken continuation with antiquity. The Shū thus became a tool of legitimacy, allowing groups to articulate even unorthodox positions with ancient backing in the debate about ruler-subject relations and good rule.

Take for example "Jīn téng" and its manuscript counterpart "Zhōu Wǔ Wáng yǒu ji”. My analysis (Ch. 5) has shown how different communities produce different stories for different ends in their recourse to the same set of materials. "Jin téng" has all the necessary clues to present the deeds of the Duke of Zhōu in the most favourable light. It behaves like a memorial to remind participating communities of the right bond between ruler and subject. As such it speaks to wider communities, including those that were somewhat removed from the memory of the event. Not so "Zhōu Wǔ Wáng yǒu jî". Its purpose is to entertain elements of doubt about the duke's actual role, so that the text recipients may 're-live' moments of despair in a prescribed, formalised setting. "Zhōu Wǔ Wáng yǒu jî" renews that bond in the present by having it re-enacted, time and again, in an audience through the act of reading it or experiencing it otherwise. In so doing it speaks to the meaning community of the Eastern Zhōu oecumene to whom the ritual significance of the event was more present. Or take the received "Gù mìng" and its relation to the manuscript text "*Băo xùn" (Ch. 4). At least in one of the two cases, if not in both, the communities in question appropriated solidified formulae that channel, and therefore prescribe, the way the event is told. In this way, they transformed a singular 'historical' situation and made it into a normative type of event - and, nota bene, one that presents a political claim that is at odds with the one formulated in the other text.

To articulate a given sociopolitical and philosophical stance within the cultural bounds of Shū genre is thus shown to be viable. It ensures that a message is articulated in such a manner that it carries authoritative value. It also shows that Shū do not record history. Of course they are are historical documents. But they are historical documents only insofar they inform us, the historian of thought, about the manifold ways Warring States communities narrativised a projected event in history by use of set patterns-defined by Shū genre-to make normative claims of sociopolitical and philosophical relevance. 
By using the voice of antiquity for present ends, the commitment to truth of the late Eastern Zhōu articulations of Shū is therefore not a matter of objectivity but of capturing an ideal that is either gone or under threat. Shū do not set out to archive historical events as they really happened. In appropriating the past for present ends, they have political relevance.

\subsection{Shū Genre and Political Argument}

Political argument understood in this way entails that within the framework of normativity as prescribed by the accepted parameters of cultural productionShū genre-a space is given to the various, sometimes competing, sub-groups of the meaning community of the day that enables flexibility, and creativity, in the making of a point that has socially patterning, as well as philosophical, relevance. That space of accepted normativity as defined by the bounds of Shū genre therefore prescribes how an argument is presented, as well as what that position may be. In their Gestus of self-representation these parameters of textualised Shu therefore bring together, as a cultural instution, articulations as disparate as “Wén Hóu zhī mìng”, "Jīn téng”, “Zhōu Wǔ Wáng yǒu jî”, “Gù mìng”, “^Băo

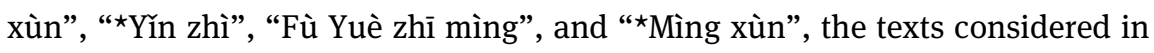
this study. ${ }^{10}$

Obviously, political argument thus defined differs from our common notion of 'politics', as is also remarked by the renowned German Classicist Christian Meier in his seminal, albeit somewhat inwardlooking, discussion of the origins of 'matters political' (das Politische) in early Greece. ${ }^{11}$ Meier defines it as the area in which there appears 'an extension of the political space to act in a given, prescribed way (Dispositionsraum), beyond the centres of rule'. ${ }^{12}$ The political space where argument is constructed to Meier is therefore where a given order is chal-

10 This list could of course be extended much further, with the Qīnghuá manuscripts now showing how vast the traditions of Shū were. A text like “`Tāng zài chì/dì mén” (Meyer 2018a), with its odd ways of constructing meaning in a performative setting, may be mentioned here. The text casts light on articulations that occupy a rather peripheral place in these traditions, demonstrating that to present an argument as Shū not only means to link the argument to a discourse; it moreover shows also how relevant such an act was-sociopolitically, philosophically or otherwise-to be linked to it.

11 C. Meier 1980: 15.

12 Ibid, $17 \mathrm{f}$. 
lenged - in fact, to him that challenge is the very expression of political argument. ${ }^{13}$ For Meier it is difficult to think of the political space of argument as disconnected from the Greek hē pólis ( $\dot{\eta} \pi o ́ \lambda ı \sigma$ ), a term referring to the politicallyqualified community of free men in the city-state. ${ }^{14}$ Yet, while for Meier the Greek polis is the prime locus of political argument, there is no good reason why 'matters political' should be restricted to one single historical-geographical constellation - as long as we allow its parameters to be adjusted. ${ }^{15}$ In other words, political argument as I use it here is a concept that applies whenever self-conceptionalised groups and sub-groups re-negotiate their space of influence. It is therefore essentially a goal-oriented act - in Greece, China, or elsewhere. That contrasting conceptual communities articulate their ideas within the bounds of Shū traditions by moving old cultural capital into new problem space so to use the past for ends in the present thus constitutes an immediate expression of this very act. It is a manifestation of re-negotiating political space.

When looking at political argument from the macro perspective of the Shū traditions, we therefore find that the parameters of Shu genre present a framework-call it cultural normativity-of expectations, a cultural mould, so to speak, that may be filled with contents of different sorts. This mould, rather than specific contents, is what presents legitimacy, and viability, to the positions articulated in the texts. "Wén Hóu zhī mìng" (Ch. 6) can thus assume the Gestus of a Western Zhōu bronze texts while really it is detached from the socio-material referentiality of such contexts; “Gù mìng” and “^Băo xùn” (Ch. 4) may be mirrored in their framing devices but present opposite sociopolitical and philosophical positions; “Zhōu Wǔ Wáng yǒu jî” (Ch. 5) develops a sophisticated dramatisation of the reported event by positing a polarisation of two historical personae. Its message

13 Ibidem.

14 Aristotle was perhaps the first to systematise matters political as a discipline by reference to the autonomy of the political structure of decision making. That there has never been an independent discourse of the nature of the political, thus making it into a discipline as initiated by Aristotle, is hardly justification of the claim that matters political, as a category, are not applicable to early China, as duly noted in an excellent discussion of that problem by Marchal 2011: 35 . 15 This point is also made in Marchal 2011: 36-37. In terms of the different bounds, Marchal notes the lack of the public in early China; the lacking isonomy of the citymen in China; as well as the absence of the Greek notion of independence in China.

Note that C. Meier's discussion is fundamentally based on Carl Schmitt's (1888-1985) concept of 'das Politische' (as defined in his coterminous essay from 1927, further refined in 1932, and with a new Introduction and added corollaries 2015) as something that constantly negotiates between friend and enemy. Within reason, this conflict is applicable to different kinds of constellations and thus presents a useful methodological framework beyond the Greek realm. 
becomes transposable to be re-used in a different setting, so that the projected experience of the king can be relived by the recipient in the present, whereas "Jin téng” serves as a textualised Denkmal to remind participating communities of the generic bond between subject and lord; “^Yĩn zhì” (Ch. 6) foregrounds the legitimacy of the Shāng in replacing the Xià by focalising on the reconstitution of the Dì, thus systematising-anachronistically-the concept of heavenly Mandate; "Fù Yuè zhī mìng" (Ch. 6) unites a group of texts that narrativise-variously-the fabula of the encounter of king and minister-to-be, Fù Yuè, to celebrate the charismatic power of the king through the deeds of the minister; “^Mìng xùn” (Ch. 6) develops a complex philosophy of rule where political power is produced, and reinforced, dialectially from the large to the small and vice versa. In so doing it develops a scheme that is continuously testing itself philosophically by producing a standard which defies becoming doctrine.

That we call these different texts Shū is because tradition informs us to do so. To the conceptual communities of the time the Shu traditions were simply the bounds of accepted normativity that allowed them to articulate an argument and have it enter debate. Naturally, those bounds were tested continuously, and they were expanding accordingly. Some articulations were thus accepted as normative within those bounds; others were not. Different conceptual sub-groups will have had different expectations. Some articulations were therefore successful and survived. Others were not and fell out of transmission processes. I therefore do not consider it productive that we identify, retrospectively, hard parameters in defining what is a Shū, and what not. The meaning community was not static but constituted by competing groups and sub-groups. Genre expectations evolve over time and differ between social groupings. Shū have thus become, I close, a genre of literary performance through which constrasting conceptual communities move old cultural capital into new argument space to (re-)negotiate political space of influence within the framework of normativity as defined by accepted models of tradition.

\subsection{Xí Jìnpíng's Shū}

I want to end by reflecting briefly on contemporaneous dimensions of the Shū traditions. To articulate an argument and address it to an imagined community by placing it in the traditions of Shū was not just done by Eastern Zhōu communities; similar strategies are used by the political cadres and social theorists in China today when they recite select statements from those traditions as they see fit in the making of a political argument. Whether the truly ancient (or downright 
invented) repertoire of a group's cultural capital is recontextualised in the continuum of history by placing it in new argument space as happening during the Warring States; or whether isolated text constituents from the Shàngshū are taken out of their context and cited purposefully in the setting of political speech by political scientists or cadres of the Chinese Communist Party today: in both cases the constituent elements of tradition as used by these groups-reproduced, recited, or invented-are treated as modular and they are thus used flexibly to (re-)negotiate spaces of influence within the normative bounds of tradition.

Having lost their heartland-and cultural legitimacy-certain communities of the Eastern Zhōu oecumene felt the need to (re-)invent the 'social contract' between ruler and ruled: a bond based on what is 'right' and exemplified by the personae of high antiquity whose voice and example of good conduct were wellknown. Parallel to the experience of the Eastern Zhōu communities, leading a 'Marxist' state that is however driven by hypercapitalism, political leaders and social theorists today feel they need to invent a unifying spirit to 'remind' the Chinese people of their common cultural roots. 'Confucianism' (whatever that really means) has been national favourite in that endeavour for quite some time, despite party leaders' repeated reference to 'Marxist values', which in their logic presents no conflict. ${ }^{16}$ Both enterprises find in Shū traditions an ideal source for their undertaking.

The Shàngshū is not the only source serving Xí Jìnpíng 習近平-President of the People's Republic of China, General Secretary of the Communist Party of China, Chairman of the Central Military Commission, and since October 2016 lifelong 'core' leader-in upholding his view that the Chinese Communist Party remains the single 'loyal inheritor and promoter of China's outstanding traditional culture'. ${ }^{17}$ This was stated in 2014 at an official visit to Qūfù 曲阜, (Shāndōng 山 東 Province) home of Confucius, the venerated persona of antiquity who had to serve as a projection surface to legitimise a variety of trends, actions, and slogans-positive as well as negative-for much of China's history, past and present. But the Shàngshū and its related texts continually take a principal role in the Party's endeavour to 'vigorously promote China's traditional culture'. ${ }^{18}$

16 Just forty-eight hours before the visit of Barack Obama to China in November 2009, the official news agency Xīnhuá released a statement by Xí Jìnpíng-nearly three years before he became the leader of the Chinese Communist Party in Autumn 2012-in which he proposed to 'actively encourage the building of a ruling party study model of Marxism'. (Sisci 2009).

17 Cited from the New York Times (11 October 2014). Buckley: “Leader Taps Into Chinese Classics in Seeking to Cement Power".

18 New York Times (11 October 2014). Xí repeatedly also makes reference to Hán Fēi 韓非 (c. 280$233 \mathrm{BC}$ ), the most prominent of the group of thinkers/texts later denoted 'Legalist' (plus Shāng 
In an address at the $18^{\text {th }}$ collective study session on governance of the Politburo, Xî Jìnpíng remarked:

Several thousand years ago, the Chinese nation trod a path that was different from other nations' culture and development... It is not a coincidence that we started up 'socialism with Chinese characteristics'... It was decided by our country's historical inheritance and cultural traditions. ${ }^{19}$

And further:

History is created by the people and so is civilization... We should be more respectful and mindful of 5,000 years of continuous Chinese culture..$^{20}$

Headed by a line from the Shàngshū, random references to statements plucked out of texts from the past follow next. The Shàngshū quotation notably reads 'the people are the basis of the state' 民惟邦本. Disconnected from its contexts and placed in its target text, that is, Xí's speech, it loses it previous reference structure. It is now a slogan in the first instance, rather than a reference to an ancient source. Combined with the phrases from other early texts, including phrases such as 'governmental affairs shall gain the people's support' 政得其民, as alluding to the Mèngzĭ, ${ }^{21}$ or 'rituals and law come together in proper rule' 禮法合治, essentially a statement of his own making but put in the form of a reference, the source texts behind these slogans blur and, decontextualised as they now are, the phrases take on a new reality in Xî's speech. ${ }^{22}$ Xî’s reference to China's cultural

Yāng 商鞅, c. 390-338 BC, known for his punitive procedures to transform the kingdom of Qín into the leading state), as well as to the constructed personae Confucius and Mencius. (In May 2015, the state-run newspaper Rénmín rỉbào 人民日報 ‘People’s Daily’ published 76 selected quotations of Xî's from Chinese classical literature.) The blatant simplicity of the propaganda in which Xí identifies the Chinese Communist Party as the single loyal inheritor of Chinese traditional culture, on the one hand, and the proclamation that the Chinese people should turn to traditional culture, on the other (in other words, they should turn to the Party) needs no further note here.

19 New York Times (14 October 2014). Tatlow: "Xi Jinping on Exceptionalism with Chinese Characteristics”, quoting Rénmín rìbào.

20 New York Times (14 October 2014).

21 The Mèngzǐ: “Lí lóu” shàng (孟子. 离娄上) reads: 得天下有道: 得其民, 斯得天下矣。得其 民有道: 得其心, 斯得民矣 'there is a way of obtaining the world: obtain the commonfolks thus is the wold obtained; there is a way of obtaining the commonfolks: obtain their heart-minds - thus are the commonfolks obtained'.

22 Altogether this fraction of his speech reads: 我國古代主張民惟邦本、政得其民, 禮法合 治、德主刑輔, 為政之要莫先于得人、治國先治吏, 為政以德、正己修身, 居安思危、改易更 化, 等等, 这些都能給人們以重要啟示. 'In antiquity, our lands maintained the principle that 
heritage is only on the surface. Entextualised in his speech, the phrases really point to something fundamentally new.

The Shàngshū, or in fact any of the texts used in Xî's speech, no longer carry any significance except that they are meant to relate to the olden days. They carry meaning qua source, not because they are particularly meaningful to the audience - if they even know the content of these texts at all! They invoke authority because in their ancient diction Xí is using them to 'remind' his audiences of the spirit of 'China's outstanding traditional culture' - not because the lines 'cited' in his speech document, or reflect upon, past events.

It is revealing that the line in Xí's speech from the Shàngshū relates to the spurious old-script “Wǔ zǐ zhī gē” 五子之歌 (The Songs of the Five Sons) of the "Xià” division, most likely of late, imperial making, unmasking Xí’s use of it as purely an act of tradition-making.

In this regard it is also relevant that in much of the Shàngshū 'min 民'-the term which features centrally in Xí's speech-had a profoundly different meaning from what we consider '(common) people' today. It is a layered concept that has little in common with the English rendering of the term, which is derived from the Latin populus, the people of the state (in opposition to the Senate), or for that matter, its modern Chinese equivalent. In much of textualised Shū the term denotes members of the aristocracy of a different state. During the Western Zhou it seems that min 'primarily refers to subjected lineages and rulers outside the Royal Domain'. ${ }^{23}$ It thus works with a conceptual division of the Zhōu kingdom into centre and periphery, ${ }^{24}$ finding a graded continuation in the Spring and Autumn period - and partly during the Warring States too. During the Warring States the term underwent further shifts such that in some texts it takes on the derived meaning of 'the commonfolks', a concept that is yet again substantially different from the present egalitarian notion of 'the people'. However, in Xí's speech, it takes on exactly this meaning, that is, the 'people', as its new reality. As a result, it is not just the term min but the cited lines more generally that change in meaning when decontextualised from the ancient sources and used in this way.

the commonfolks form the roots of a state and obtain the folks through moral governance; rituals and law cohere in order, and virtue rules punishments; to govern cannot but first obtain the commonfolks; to order the lands cannot but first order the officials. To govern with virtue is to correct oneself and cultivate the person. Dwell in tranquillity pondering danger; transformation furthers change, and so forth. These are all measures that enable to offer important insight to the people'.

23 Crone 2016.

24 Crone 2014. 
Through recourse to the Shàngshū, Xí thus roots himself-and so the entire Chinese Communist Party-in an invented tradition. It is in this continuously revised form that the past shapes contrasting presents. By taking stance in the 'continuum of Chinese antiquity' to stress the bond of ruler and ruled, thus moving old cultural capital into a new problem space, Xí is essentially articulating his own Shū - a political act as countless communities have done before him.

I do not wish to draw from this the conclusion that the power structures of the centralist Marxist state, the People's Republic of China, are in any way structurally parallel to those of the Warring States, where competing sub-groups of the wider meaning community of the Zhōu oecumene articulate their stance as Shū to capitalise on cultural memory for ends in the present. Quite the contrary. I cite this new iteration because it is illustrative of the generative power of the Shū, even today, demonstrating the significance of these traditions, and thus the appeal of using them in political discourse. 
